\title{
Interface Behavior between Normal Concrete and Fibre Reinforced High Performance Concrete
}

\author{
Tara Boby \\ PG Scholar Computer Aided Structural Engineering Mar Athanasius College of Engineering \\ Kothamangalam, Kerala 686666, India. \\ Nivin Philip \\ Assistant Professor Department of Civil Engineering Mar Athanasius College of Engineering \\ Kothamangalam, Kerala 686666, India.
}

\begin{abstract}
The development of an effective and durable repair system is essential due to the early and premature deterioration of reinforced concrete structures.High-performance concrete (HPC) exceeds the properties and constructability of normal concrete.Optimum percentage of metakaolin, ALCCOFINE 1203 and steel fibres are incorporated in the design mix to obtain the desired fibre reinforced high performance concrete.Mechanical and durability properties of the concrete were tested.The interfacial bond characteristics were assessed on the interface between normal concrete and fibre reinforced high performance concrete by conducting the slant shear test and splitting tensile strength. The use of fibre reinforced high performance concrete to provide an effective and durable concrete repair to normal concrete is studied.
\end{abstract}

\section{Introduction}

With the development of modern civil engineering structures, the need to develop higher performance construction materials with high strength, toughness, energy absorption, durability and so on have come into being.High performance concrete is a specialized series of concretes designed to provide several benefits in the construction of concrete structures.HPC exceeds the properties and constructability of normal concrete.Fibre reinforced concrete is a composite material made with Portland cement, aggregate, and incorporating discrete discontinuous fibres.Steel fibre reinforced high performance concrete is increasingly developing and making remarkable progress during recent years.It is an important high performance concrete, especially used in the repair work for highways, pavements, bridge decks etc.

The early and premature deterioration of reinforced concrete structures is a serious issue for many nations and the concrete repairs provided lack both early age performance and longterm durability. Therefore it is essential to develop an effective and durable repair system.In the field of retrofitting and strengthening of concrete structures, the need to place repair material next to old concrete often arise. A good, efficient and durable bonding is one of the main requirement for effective and successful repair.

The main objective of the study is to determine the optimum design mix for M100 grade concrete containing metakaolin, ALCCOFINE 1203 and steel fibres.The durability properties of this M100 grade concrete are studied.Also the interfacial bond characteristics between normal concrete and fibre reinforced high performance concrete are evaluated.In order to assess the bond characteristics, slant shear test and splitting tensile test is conducted.

\section{Materials Used}

Grade-53 Ordinary Portland Cement conforming to IS specifications was used in this study.Fine aggregate belong to ZONE II category.Nominal size of coarse aggregate used is $12 \mathrm{~mm}$.Water-cement ratio of 0.25 was used.Metakaolin and ALCCOFINE 1203 are the two mineral admixtures used in the design mix.The properties of metakaolin and ALCCOFINE 1203 are given in Table 1 and Table 2 respectively.The super plasticizer used is Master Glenium Sky 8233 and the properties are given in Table 3.Flat crimped steel fibres of 10mm length are also used in the mix (Fig 1).The specification of flat crimped steel fibre is given in Table 4.

TABLE 1.Properties of Metakaolin

\begin{tabular}{|c|c|}
\hline \multicolumn{2}{|c|}{ CHEMICAL COMPOSITION (\%) } \\
\hline $\mathrm{SiO}_{2}$ & 52.1 \\
\hline $\mathrm{Al}_{2} \mathrm{O}_{3}$ & 42.8 \\
\hline $\mathrm{Fe}_{2} \mathrm{O}_{3}$ & 1.6 \\
\hline $\mathrm{CaO}$ & 0.2 \\
\hline $\mathrm{MgO}$ & 0.21 \\
\hline $\mathrm{SO}_{3}$ & 0.00 \\
\hline $\mathrm{K}_{2} \mathrm{O}$ & 0.32 \\
\hline $\mathrm{Na}^{2} \mathrm{O}$ & 0.11 \\
\hline \multicolumn{2}{|c|}{ PHYSICAL PROPERTIES } \\
\hline Specific surface $\left(\mathrm{m}^{2} / \mathrm{g}\right)$ & 2.54 \\
\hline Specific gravity & 2.6 \\
\hline
\end{tabular}

TABLE 2.Properties of ALCCOFINE 1203

\begin{tabular}{|c|c|c|c|c|c|}
\hline \multirow[t]{2}{*}{$\begin{array}{l}\text { Fineness } \\
\left(\mathrm{cm}^{2} / \mathrm{gm}\right)\end{array}$} & \multirow[t]{2}{*}{$\begin{array}{l}\text { Specific } \\
\text { Gravity }\end{array}$} & \multirow{2}{*}{$\begin{array}{c}\text { Bulk } \\
\text { Density } \\
\left(\mathrm{kg} / \mathbf{m}^{3}\right) \\
\end{array}$} & \multicolumn{3}{|c|}{$\begin{array}{l}\text { PARTICLE SIZE } \\
\text { DISTRIBUTION }\end{array}$} \\
\hline & & & $\mathrm{d} 10$ & $\mathrm{~d} 50$ & d90 \\
\hline$>12000$ & 2.9 & $700-900$ & 1.5 micron & 5 micron & 9 micron \\
\hline \multicolumn{6}{|c|}{ CHEMICAL PROPERTIES } \\
\hline $\mathrm{CaO}$ & $\mathrm{SO}_{3}$ & $\mathrm{SiO}_{2}$ & $\mathrm{Al}_{2} \mathrm{O}_{3}$ & $\mathrm{Fe}_{2} \mathrm{O}_{3}$ & $\mathrm{MgO}$ \\
\hline $61-64 \%$ & $2-2.4 \%$ & $21-23 \%$ & $5-5.6 \%$ & $3.8-4.4 \%$ & $0.8-1.4 \%$ \\
\hline
\end{tabular}


TABLE 3.Properties of Master Glenium Sky8233

\begin{tabular}{|c|c|}
\hline PROPERTY & VALUE \\
\hline Aspect & Light brown liquid \\
\hline $\mathrm{Ph}$ & $>=6$ \\
\hline Relative density & $1.08 \pm 0.01$ at $25^{\circ} \mathrm{c}$ \\
\hline Chloride ion content & $<0.2 \%$ \\
\hline
\end{tabular}

TABLE 4.Specification of flat crimped steel fibre

\begin{tabular}{|c|c|}
\hline PROPERTY & SPECIFICATION \\
\hline Length of Fibre (1) & $10 \mathrm{~mm}$ \\
\hline Aspect ratio & 45 \\
\hline Diameter (d) & $0.6-0.8 \mathrm{~mm}$ \\
\hline Width (w) & $2 \mathrm{~mm}-2.5 \mathrm{~mm}$ \\
\hline Tensile Strength & $600 \mathrm{MPa}$ \\
\hline $\begin{array}{c}\text { Appearance and } \\
\text { Form }\end{array}$ & $\begin{array}{c}\text { Clear, bright and undulated along the } \\
\text { length }\end{array}$ \\
\hline Material Type & Low Carbon Drawn Flat Wire \\
\hline
\end{tabular}

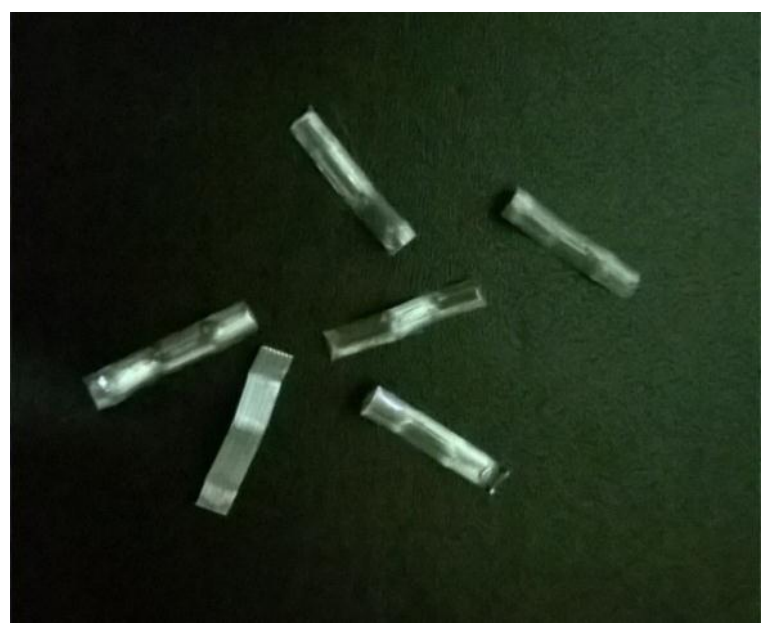

Fig 1.Flat Crimped steel fibre

\section{Optimum Mix}

3.1 Optimum Percentage Replacement of ALCCOFINE 1203

The high performance concrete used in the experimental program is of grade M100 and it was designed according to ACI 211.4R [17].Compression test is performed on cubical specimens of size 150 X $150 \times 150 \mathrm{~mm}$ to determine the optimum design mix for M100 grade concrete.The replacement level of metakaolin is fixed as $5 \%$ and the ALCCOFINE 1203 replacement level is varied from $4 \%$ to $12 \%$ at $2 \%$ interval.The specimen corresponding to maximum compressive strength is chosen as the optimum design mix.The mix proportions for high performance concrete are given in Table 5.
TABLE 5.Mix design of M100

\begin{tabular}{|c|c|c|}
\hline CONTENTS & $\begin{array}{l}\text { VOLUME } \\
\text { FOR 1 } \mathbf{m}^{3}\end{array}$ & $\begin{array}{c}\text { QUANTITY } \\
\left(\mathrm{kg} / \mathrm{m}^{\mathbf{3}}\right)\end{array}$ \\
\hline Cement & 0.174 & 550 \\
\hline Coarse aggregate & \multirow[b]{2}{*}{0.6856} & 1100 \\
\hline Fine aggregate & & 672 \\
\hline Chemical admixture & 0.00288 & 3.3 \\
\hline Water & 0.1375 & 137.5 \\
\hline Water-cement ratio & \multicolumn{2}{|c|}{0.25} \\
\hline \multicolumn{3}{|l|}{ Mineral Admixture } \\
\hline Metakaolin & \multicolumn{2}{|c|}{$5 \%$ replacement of cement } \\
\hline $\begin{array}{l}\text { ALCCOFINE } \\
1203\end{array}$ & \multicolumn{2}{|c|}{$\begin{array}{l}\text { Varied from } 4 \% \text { to } 12 \% \\
\text { replacement of cement }\end{array}$} \\
\hline
\end{tabular}

The 7 day and 28 day compressive strength of the specimens with various percentage levels of ALCCOFINE 1203 are given in Table 6 and Fig 2 shows the variation in compressive strength for different replacements of ALCCOFINE 1203.

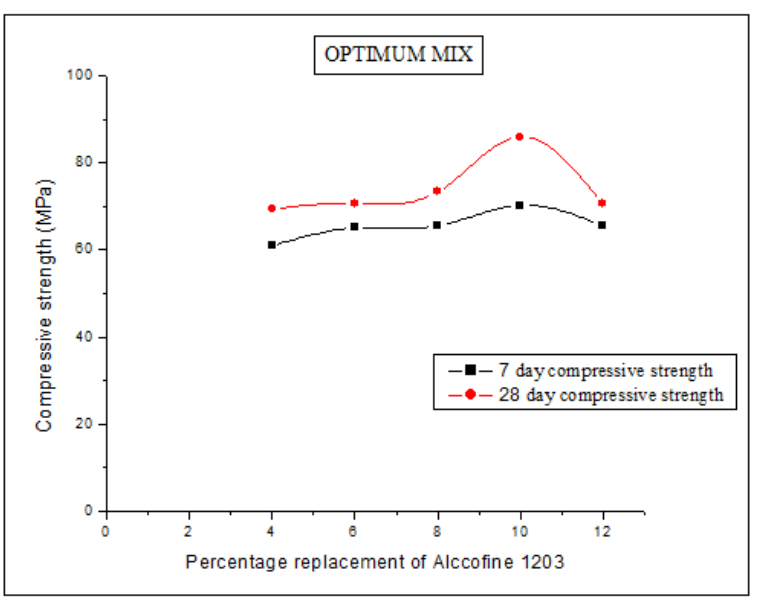

Fig 2.Compressive strength for various percentage replacement of ALCCOFINE 1203

Maximum value of 7 day compressive strength is found to be $70.22 \mathrm{MPa}$ and maximum value of 28 day compressive strength is found to be $85.92 \mathrm{MPa}$.The maximum values of compressive strength are obtained for the mix containing $10 \%$ of ALCCOFINE 1203.Therefore, the optimum design mix of M100 grade concrete contains 5\% replacement of Metakaolin and $10 \%$ replacement of ALCCOFINE 1203.

\subsection{Optimum Percentage of Steel Fibres}

In order to obtain the optimum design mix, the concrete mix is impregnated with different percentages of steel fibres.28 days compressive strength of the samples with $0.1 \%, 0.3 \%, 0.4 \%$, $0.7 \%$ and $1 \%$ fibre variations are determined.Table 7 shows compressive strength for different percentage of steel fibre.The effect of fibre variation on compressive strength of concrete is shown on Fig 3.The percentage of steel fibre corresponding to maximum compressive strength is adopted in the design mix. 
TABLE 7.Compressive strength for different percentage of steel fibre.

\begin{tabular}{|c|c|}
\hline $\begin{array}{c}\text { FIBRE } \\
\text { VARIATION }\end{array}$ & $\begin{array}{c}\text { 28 DAYS COMPRESSIVE } \\
\text { STRENGTH (MPa) }\end{array}$ \\
\hline $0.1 \%$ & 45.93 \\
\hline $0.3 \%$ & 70.37 \\
\hline $0.4 \%$ & 65.26 \\
\hline $0.7 \%$ & 53.60 \\
\hline $1 \%$ & 56.10 \\
\hline
\end{tabular}

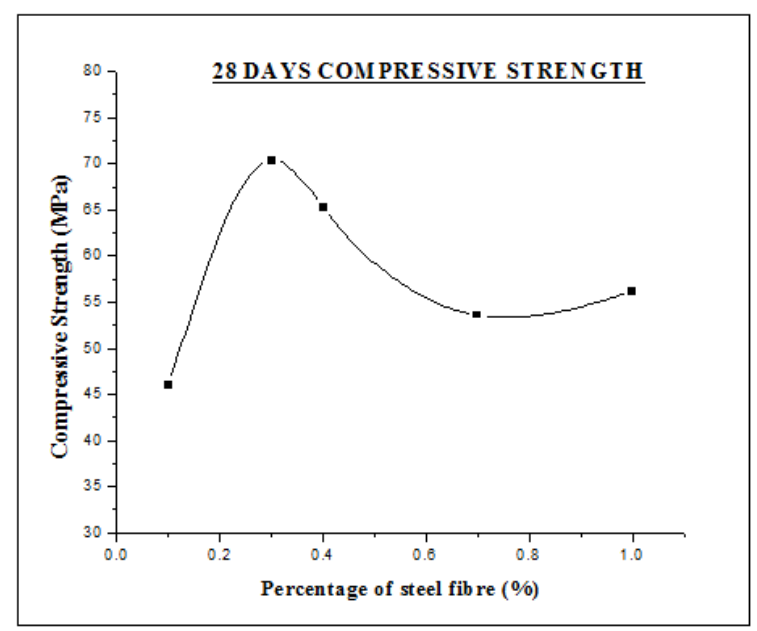

Fig 3.Effect of fibre variation on compressive strength

From Table 7, the maximum value of 28 days compressive strength is obtained to be $70.37 \mathrm{MPa}$ for mix containing $0.3 \%$ steel fibre.Therefore the optimum percentage of steel fibre adopted in the design mix is $0.3 \%$.

\section{TABLE 6.Compressive Strength for various percentage replacements of ALCCOFINE 1203}

\begin{tabular}{|c|c|c|c|c|c|c|c|}
\hline \multirow{2}{*}{$\begin{array}{c}\text { SPECIM } \\
\text { EN }\end{array}$} & \multirow{2}{*}{$\begin{array}{c}\text { SAMP } \\
\text { LE }\end{array}$} & \multicolumn{3}{|c|}{7 DAYS } & \multicolumn{3}{|c|}{28 DAYS } \\
\hline & & $\begin{array}{c}\text { LOA } \\
\text { D } \\
(\mathbf{k N})\end{array}$ & $\begin{array}{l}\text { COMPRES } \\
\text { SIVE } \\
\text { STRENGT } \\
\text { H } \\
\text { (MPa) }\end{array}$ & $\begin{array}{c}\text { AVERA } \\
\text { GE }\end{array}$ & $\begin{array}{c}\text { LOA } \\
\text { D } \\
(\mathrm{kN})\end{array}$ & $\begin{array}{c}\text { COMPRES } \\
\text { SIVE } \\
\text { STRENGT } \\
\text { H } \\
\text { (MPa) }\end{array}$ & $\begin{array}{c}\text { AVERA } \\
\text { GE }\end{array}$ \\
\hline \multirow{3}{*}{\begin{tabular}{|c|} 
E4 \\
$(4 \%$ \\
ALCCOF \\
INE \\
$1203)$ \\
\end{tabular}} & 1 & 1450 & 64.44 & \multirow[t]{3}{*}{60.89} & 1570 & 69.77 & \multirow[t]{3}{*}{69.48} \\
\hline & 2 & 1310 & 58.22 & & 1530 & 68.00 & \\
\hline & 3 & 1350 & 60.00 & & 1590 & 70.67 & \\
\hline \multirow{3}{*}{\begin{tabular}{|c|} 
E6 \\
$(6 \%$ \\
ALCCOF \\
INE \\
$1203)$ \\
\end{tabular}} & 1 & 1460 & 64.88 & \multirow[t]{3}{*}{65.03} & 1580 & 70.22 & \multirow[t]{3}{*}{70.67} \\
\hline & 2 & 1540 & 68.44 & & 1590 & 70.67 & \\
\hline & 3 & 1390 & 61.78 & & 1600 & 71.11 & \\
\hline \multirow{3}{*}{\begin{tabular}{|c|} 
E8 \\
$(8 \%$ \\
ALCCOF \\
INE \\
$1203)$ \\
\end{tabular}} & 1 & 1550 & 68.88 & \multirow[t]{3}{*}{66.07} & 1620 & 72.00 & \multirow[t]{3}{*}{73.33} \\
\hline & 2 & 1470 & 65.33 & & 1660 & 73.77 & \\
\hline & 3 & 1440 & 64.00 & & 1670 & 74.22 & \\
\hline \multirow{3}{*}{\begin{tabular}{|c|} 
E10 \\
$(10 \%$ \\
ALCCOF \\
INE \\
$1203)$ \\
\end{tabular}} & 1 & 1590 & 70.67 & \multirow[t]{3}{*}{70.22} & 1930 & 85.77 & \multirow[t]{3}{*}{85.92} \\
\hline & 2 & 1570 & 69.78 & & 1980 & 88.00 & \\
\hline & 3 & 1580 & 70.22 & & 1890 & 84.00 & \\
\hline
\end{tabular}

\begin{tabular}{|c|c|c|c|c|c|c|c|}
\hline E12 & 1 & 1460 & 64.88 & 65.48 & 1580 & 70.22 & 70.67 \\
\cline { 2 - 4 }$(12 \%$ & 2 & 1510 & 67.11 & & 1670 & 74.22 & \\
ALCCOF & 3 & 1450 & 64.44 & & 1520 & 67.56 & \\
INE & & & & & & & \\
$1203)$ & & & & & & & \\
\hline
\end{tabular}

\section{Mechanical Property of HPC}

4.1 Compressive Strength

To study the influence of Metakaolin, ALCCOFINE 1203 and steel fibres on M100, compressive test was performed on cubical specimens of size 150 X 150 X $150 \mathrm{~mm}$. The mix contains $5 \%$ replacement of Metakaolin, $10 \%$ replacement of ALCCOFINE 1203 and $0.3 \%$ of flat crimped steel fibres.The test was conducted according to IS 516 (1989) [11].The compressive test results of the samples on 7, 28 and 90 days are summarized in Table 8.

TABLE 8.Compressive strength

\begin{tabular}{|c|c|c|c|c|c|}
\hline SPECIMEN & SAMPLE & $\begin{array}{c}\text { WEIGHT } \\
(\mathbf{k g})\end{array}$ & $\begin{array}{c}\text { LOAD } \\
(\mathbf{k N})\end{array}$ & $\begin{array}{c}\text { COMPRESSIVE } \\
\text { STRENGTH } \\
(\mathbf{M P a})\end{array}$ & $\begin{array}{c}\text { AVERAGE } \\
\text { COMPRESSIVE } \\
\text { STRENGTH (MPa) }\end{array}$ \\
\hline \multirow{4}{*}{ ES-7 DAYS } & 1 & 8.288 & 1885.50 & 83.8 & \multirow{2}{*}{84.930} \\
\cline { 2 - 5 } & 2 & 8.310 & 1993.50 & 88.6 & \\
\cline { 2 - 5 } & 3 & 8.205 & 1854.00 & 82.4 & \\
\hline ES-28 DAYS & 1 & 8.420 & 2349.00 & 104.4 & \multirow{2}{*}{101.867} \\
\cline { 2 - 5 } & 2 & 8.350 & 2281.50 & 101.4 & \\
\cline { 2 - 5 } & 3 & 8.295 & 2245.50 & 99.8 & \multirow{2}{*}{109.267} \\
\hline ES-90 DAYS & 1 & 8.302 & 2448.00 & 108.8 & \\
\cline { 2 - 5 } & 2 & 8.321 & 2411.00 & 111.6 & \\
\cline { 2 - 5 } & 3 & 8.325 & 2416.50 & 107.4 & \\
\hline
\end{tabular}

\subsection{Discussions}

The 28 day compressive strength of M100 concrete containing 5\% Metakaolin, $10 \%$ ALCCOFINE and $0.3 \%$ steel fibre is obtained as $101.867 \mathrm{MPa}$ which is found to attain the target strength of $100 \mathrm{MPa}$.

\section{Durability Properties of HPC}

5.1 Water Absorption

The water absorption test was conducted on concrete cubes of size $150 \times 150 \times 150 \mathrm{~mm}$. The water absorption test was carried according to ASTM C 642 [13].Three specimens each were tested at the ages 28, 56 and 90 days and the average values are reported in Table 9.

\subsection{Chloride Ion Penetration}

Cube specimens of size $150 \times 150 \times 150 \mathrm{~mm}$ were cast and the effect of sea water was tested after a period of 28, 56 and 90 days. The test is conducted according to the specifications in ACI 201.2 [14].The test results are summarized in Table 10 .

\subsection{Sulphate Attack}

To study the effect of sulphate solution on the durability of concrete, cube specimens of size $150 \times 150 \times 150 \mathrm{~mm}$ were cast.Compressive strength of the specimens are determined after 28, 56 and 90 days of immersion in magnesium sulphate solution with concentration of $50000 \mathrm{ppm}$. The test is conducted according to the specifications in ASTM-C-452 
and ASTM-C-1012 ([15], [16]).The test results are summarized in Table 11.

TABLE 9.Water Absorption

\begin{tabular}{|c|c|c|c|c|c|}
\hline $\begin{array}{c}\text { SPECIM } \\
\text { EN }\end{array}$ & $\begin{array}{c}\text { SAMP } \\
\text { LE }\end{array}$ & $\begin{array}{c}\text { WET } \\
\text { WEIG } \\
\text { HT } \\
\text { W }_{1}(\mathrm{~kg})\end{array}$ & $\begin{array}{c}\text { OVEN } \\
\text { DRY } \\
\text { WEIG } \\
\text { HT } \\
\text { W }_{2}(\mathrm{~kg})\end{array}$ & \begin{tabular}{|c} 
WATER \\
ABSORPTI \\
ON \\
$(\%)=(W 1-$ \\
$\left.W_{2}\right)$ \\
$* 100 / W_{2}$ \\
\end{tabular} & $\begin{array}{l}\text { AVERAGE } \\
\text { WATER } \\
\text { ABSORPTI } \\
\text { ON } \\
(\%)\end{array}$ \\
\hline WA & 1 & 8.209 & 8.05 & 1.975 & \multirow[t]{3}{*}{1.783} \\
\hline \multirow{2}{*}{28 DAYS } & 2 & 8.244 & 8.12 & 1.527 & \\
\hline & 3 & 8.250 & 8.10 & 1.847 & \\
\hline \multirow{3}{*}{$\begin{array}{c}\text { WA } \\
56 \text { DAYS }\end{array}$} & 1 & 8.234 & 8.055 & 2.222 & \multirow[t]{3}{*}{1.964} \\
\hline & 2 & 8.327 & 8.196 & 1.598 & \\
\hline & 3 & 8.273 & 8.105 & 2.073 & \\
\hline \multirow{3}{*}{$\begin{array}{c}\text { WA } \\
90 \text { DAYS }\end{array}$} & 1 & 8.347 & 8.144 & 2.492 & \multirow[t]{3}{*}{2.057} \\
\hline & 2 & 8.205 & 8.057 & 1.836 & \\
\hline & 3 & 8.284 & 8.134 & 1.844 & \\
\hline
\end{tabular}

TABLE 10.Chloride ion penetration

\begin{tabular}{|c|c|c|c|c|c|}
\hline SPECIMEN & SAMPLE & $\begin{array}{c}\text { WEIGHT } \\
(\mathbf{k g})\end{array}$ & $\begin{array}{c}\text { LOAD } \\
(\mathbf{k N})\end{array}$ & $\begin{array}{c}\text { RESIDUAL } \\
\text { COMPRESSIVE } \\
\text { STRENGTH (MPa) }\end{array}$ & $\begin{array}{c}\text { AVERAGE } \\
\text { RESIDUAL } \\
\text { COMPRESSIVE } \\
\text { STRENGTH (MPa) }\end{array}$ \\
\hline \multirow{2}{*}{ ES-SA } & 1 & 8.352 & 2200.50 & 97.8 & \multirow{2}{*}{86.53} \\
\cline { 2 - 5 } & 2 & 8.377 & 2232.00 & 99.2 & \\
\cline { 2 - 5 } ES-SA & 3 & 8.250 & 2151.00 & 95.6 & \multirow{2}{*}{85.67} \\
\cline { 2 - 5 } 56 DAYS & 2 & 8.302 & 2178.00 & 96.8 & \multirow{2}{*}{92.86} \\
\cline { 2 - 5 } & 3 & 8.229 & 2106.00 & 93.6 & \\
\hline ES-SA & 1 & 8.256 & 2119.50 & 95.2 & \\
\cline { 2 - 5 } 90 DAYS & 2 & 8.219 & 2061.00 & 91.6 & \multicolumn{2}{|c}{} \\
\cline { 2 - 5 } & 3 & 8.250 & 2088.00 & 92.8 & \multicolumn{2}{|c}{} \\
\hline
\end{tabular}

TABLE 11.Sulphate Attack

\begin{tabular}{|c|c|c|c|c|c|}
\hline SPECIMEN & STMPLE & $\begin{array}{c}\text { WEIGHT } \\
(\mathrm{kg})\end{array}$ & $\begin{array}{c}\text { LOAD } \\
(\mathbf{k N})\end{array}$ & \begin{tabular}{|c|} 
RESIDUAL \\
COMPRESSIVE \\
STRENGTH (MPa)
\end{tabular} & $\begin{array}{c}\text { AVERAGE } \\
\text { RESIDUAL } \\
\text { COMPRESSIVE } \\
\text { STRENGTH (MPa) }\end{array}$ \\
\hline \multirow{3}{*}{$\begin{array}{c}\text { ES-SA } \\
28 \text { DAYS }\end{array}$} & 1 & 8.385 & 2173.50 & 96.6 & \multirow[t]{3}{*}{96.73} \\
\hline & 2 & 8.335 & 2155.50 & 95.8 & \\
\hline & 3 & 8.355 & 2200.50 & 97.8 & \\
\hline \multirow{3}{*}{$\begin{array}{c}\text { ES-SA } \\
56 \text { DAYS }\end{array}$} & 1 & 8.294 & 2133.00 & 94.8 & \multirow[t]{3}{*}{94.86} \\
\hline & 2 & 8.365 & 2151.00 & 95.6 & \\
\hline & 3 & 8.255 & 2119.50 & 94.2 & \\
\hline \multirow{3}{*}{$\begin{array}{c}\text { ES-SA } \\
90 \text { DAYS }\end{array}$} & 1 & 8.224 & 2020.50 & 89.8 & \multirow[t]{3}{*}{91.20} \\
\hline & 2 & 8.265 & 2052.00 & 91.2 & \\
\hline & 3 & 8.301 & 2083.50 & 92.6 & \\
\hline
\end{tabular}

\subsection{Discussions}

1) The percentage of water absorption for the samples are obtained as $1.783 \%, 1.964 \%$ and $2.057 \%$ for 28days, 56days and 90 days of immersion in water respectively.The water absorption values obtained is less than $5 \%$ and hence it is regarded as low absorption type as per ASTM C-642.

2) After 28 days of water curing the samples are immersed in sea water to study the effect of chloride ion penetration. The percentage reductions in the strength of the samples are observed to be $4.257 \%$, $6.545 \%$ and $8.842 \%$ for 28 days, 56 days and 90 days of immersion in sea water.Therefore there is a slight reduction in strength with immersion in sea water.

3) Similarly after 28 days of water curing the samples are immersed in $\mathrm{MgSO}_{4}$ solution to study the effect of sulphate attack on concrete.The percentage reductions in the strength of the samples are observed to be $5.043 \%, 6.878 \%$ and $10.470 \%$ for 28 days, 56 days and 90 days of immersion in sulphate solution.Therefore there is a slight reduction in strength with immersion in sulphate solution.

\section{Study on Interfacial Bond Characteristics}

Each of the tested specimens comprised two materials: NC as substrate and HPC as repair material.Mix proportion for HPC is given in Table 5.The normal concrete is of grade M30 and it was designed according to IS 10262:2009 [7].The mix design adopted for M30 normal concrete is shown in Table 12.

TABLE 12.Mix design of M30

\begin{tabular}{|c|c|c|}
\hline CONTENTS & $\begin{array}{c}\text { VOLUME FOR } \\
\mathbf{1 ~ m}^{\mathbf{3}}\end{array}$ & $\begin{array}{c}\text { QUANTITY } \\
\left(\mathbf{k g} / \mathbf{m}^{\mathbf{3}}\right)\end{array}$ \\
\hline Cement & 0.119 & 375 \\
\hline Coarse aggregate & 0.7136 & 1218.83 \\
\cline { 1 - 2 } Fine aggregate & 0.000375 & 704.109 \\
\cline { 1 - 3 } $\begin{array}{c}\text { Chemical } \\
\text { admixture }\end{array}$ & 0.167 & 0.375 \\
\hline Water & 0.45 \\
\hline $\begin{array}{c}\text { Water -cement } \\
\text { ratio }\end{array}$ & \multicolumn{2}{|c}{167} \\
\hline
\end{tabular}

NC substrate specimens were cast and bonded to HPC.In this study, the type of surface roughening method adopted is grooved (GR) surface, with $10 \mathrm{~mm}$ width and $5 \mathrm{~mm}$ depth.Fig 4 shows the NC substrate halves of the test samples with grooved surface preparation.

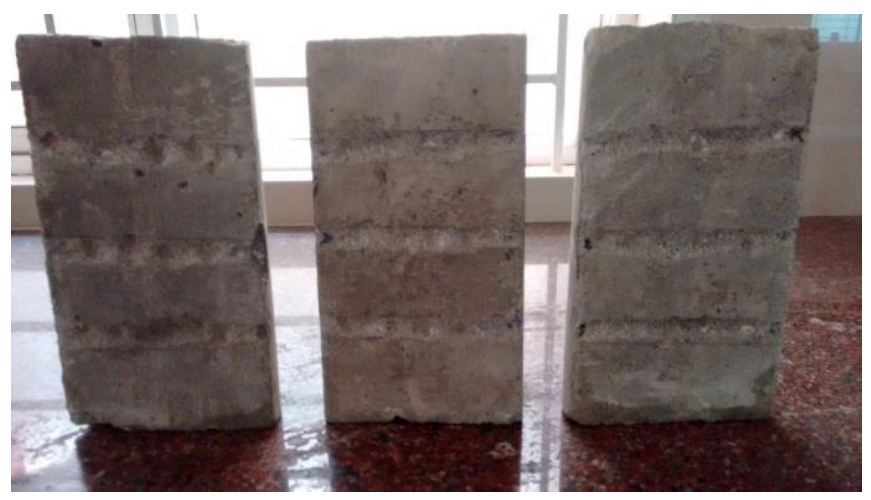

Fig 4.NC substrate halves of the samples with grooved surface texture.

\subsection{Test Procedure}

\subsubsection{Slant Shear Test}

The slant shear test method as per ASTM C882 [4] was adopted.This test was used in this study to determine the bond 
strength between the NC substrate and the HPC.Following this test procedures, HPC was cast and bonded to the NC substrate specimens on a slant plane inclined vertically at an angle of $30^{\circ}$ to form composite prism specimens of size 100 $\mathrm{mm} \times 100 \mathrm{~mm} \times 300 \mathrm{~mm}$.Fig 5 shows the composite specimen for slant shear test and Fig 6 shows the slant shear test set-up for the composite specimen.

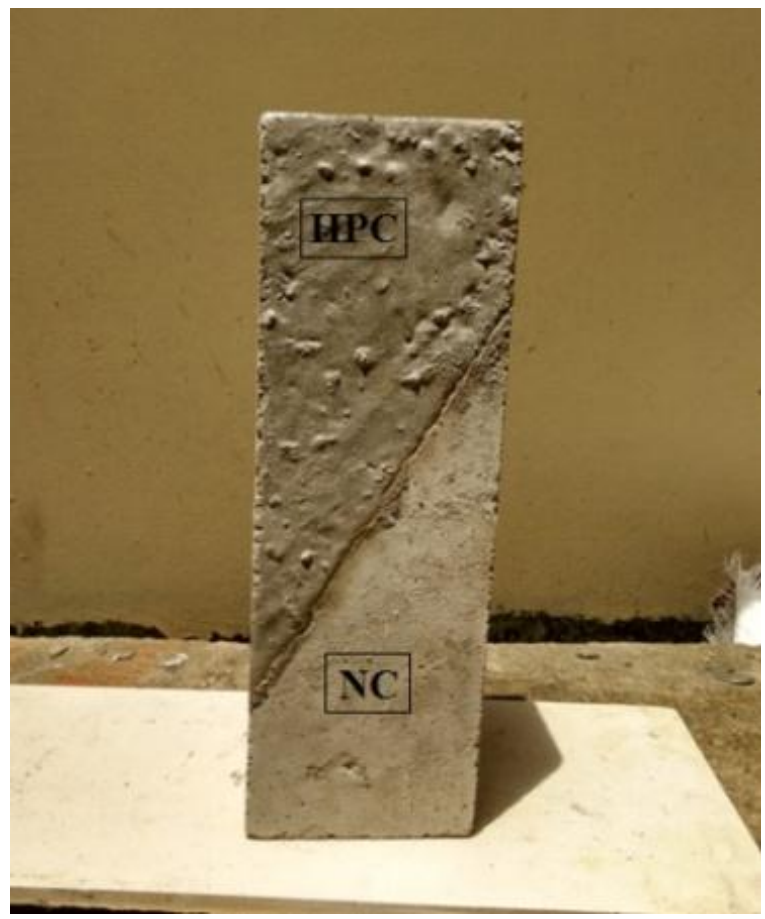

Fig 5.Composite specimen for slant shear test.

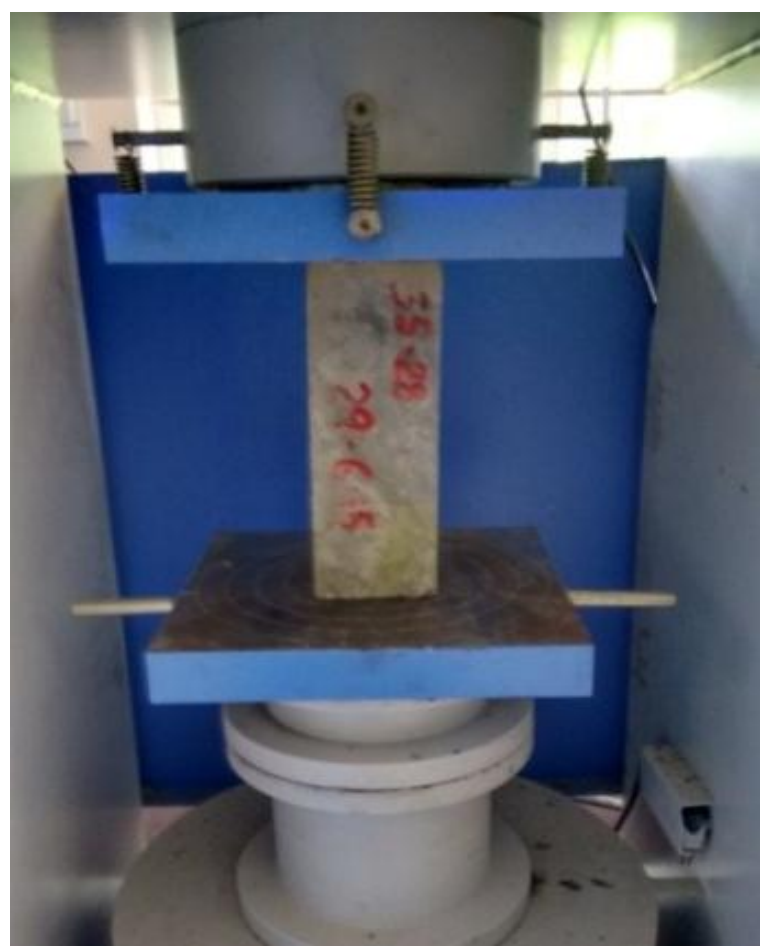

Fig 6.Slant shear test set-up for the composite specimen.
HPC is casted with and without steel fibre.The bond strength of the composite specimen with and without steel fibre is shown in Table 13.Fig 7 shows the variation in slant shear bond strength for samples with and without steel fibre.

Generally the failure modes are grouped into three distinct forms.

a) TYPE A: Pure interfacial failure where no cracking and fracturing can be observed at both the $\mathrm{NC}$ substrate and HPC overlay.

b) TYPE B: Interfacial failure combined with minor NC substrate cracking or damage.

c) TYPE C: Interfacial failure combined with substrate fracture.

TABLE 13.Slant Shear Test results

\begin{tabular}{|c|c|c|c|c|c|c|c|}
\hline \multicolumn{2}{|c|}{$\begin{array}{c}\text { SPECIME } \\
\mathbf{N}\end{array}$} & $\begin{array}{c}\text { SAMP } \\
\text { LE }\end{array}$ & \begin{tabular}{|c} 
WEIG \\
HT (kg)
\end{tabular} & $\begin{array}{c}\text { LOA } \\
\text { D } \\
(\mathbf{k N})\end{array}$ & \begin{tabular}{|c} 
BOND \\
STRENG \\
TH (MPa)
\end{tabular} & \begin{tabular}{|l} 
AVERAG \\
E BOND \\
STRENG \\
TH $(\mathrm{MPa})$
\end{tabular} & $\begin{array}{c}\text { TYPE } \\
\text { OF } \\
\text { FAILU } \\
\text { RE }\end{array}$ \\
\hline \multirow{6}{*}{$\begin{array}{l}\text { HPC } \\
\text { with } \\
\text { fibre }\end{array}$} & SS & 1 & 7.688 & 261.8 & 13.090 & \multirow[t]{3}{*}{12.572} & TYPE B \\
\hline & 7 & 2 & 7.326 & 240.0 & 12.000 & & TYPE C \\
\hline & $\begin{array}{c}\text { DAY } \\
\text { S }\end{array}$ & 3 & 7.455 & 252.5 & 12.625 & & TYPE B \\
\hline & SS & 1 & 7.492 & 273.2 & 13.660 & \multirow[t]{3}{*}{14.195} & TYPE C \\
\hline & 28 & 2 & 7.524 & 290.0 & 14.500 & & TYPE C \\
\hline & $\begin{array}{c}\text { DAY } \\
\text { S }\end{array}$ & 3 & 7.455 & 288.5 & 14.425 & & TYPE C \\
\hline \multirow{6}{*}{$\begin{array}{l}\text { HPC } \\
\text { witho } \\
\text { ut } \\
\text { fibre }\end{array}$} & $\mathrm{S}$ & 1 & 7.531 & 77.6 & 3.88 & \multirow[t]{3}{*}{3.793} & TYPE A \\
\hline & 7 & 2 & 7.456 & 74.4 & 3.72 & & TYPE $A$ \\
\hline & $\begin{array}{c}\text { DAY } \\
\text { S }\end{array}$ & 3 & 7.445 & 75.6 & 3.78 & & TYPE $A$ \\
\hline & $\mathrm{S}$ & 1 & 7.563 & 171.8 & 8.59 & \multirow[t]{3}{*}{8.573} & TYPE C \\
\hline & 28 & 2 & 7.571 & 168.4 & 8.42 & & TYPE C \\
\hline & $\begin{array}{c}\text { DAY } \\
\text { S }\end{array}$ & 3 & 7.587 & 174.2 & 8.71 & & TYPE C \\
\hline
\end{tabular}

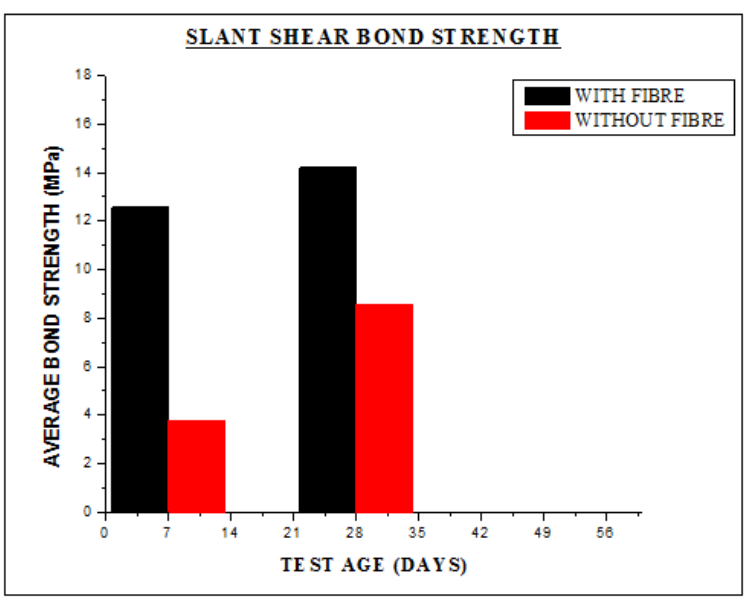

Fig 7.Slant shear bond strength for samples with and without steel fibre

\subsubsection{Splitting Tensile Strength}

The splitting tensile test as per ASTM C496 [5], as an indirect tensile test, was conducted to evaluate the bond strength between the NC substrate and HPC.In this test procedures, HPC was cast and bonded to the NC substrate specimens to 
form a cylindrical composite sample of $100 \mathrm{~mm}$ diameter and $200 \mathrm{~mm}$ height.Fig 8 shows the composite specimen for splitting tensile test and Fig 9 shows the splitting tensile test set-up for the composite specimen.

Generally the failure modes are grouped into 2 distinct forms.

a) TYPE A: Pure interface failure where no cracking and fracture can be observed at both NC substrate and HPC overlay.

b) TYPE B: Interface failure combined with partial substratum failure.

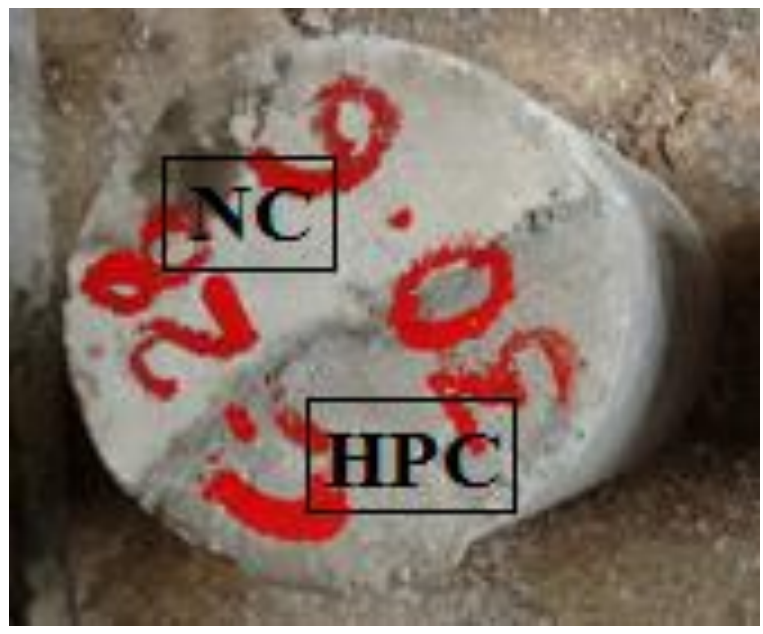

Fig 8.Composite specimen for splitting tensile test.

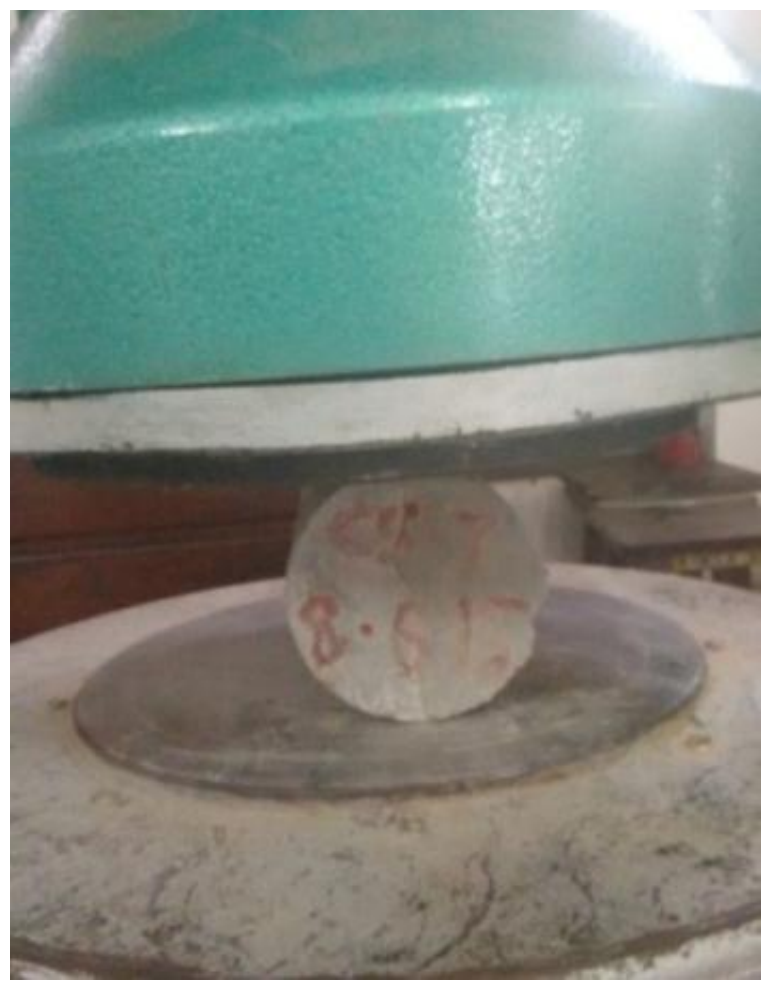

Fig 9.Splitting tensile test set-up for the composite specimen.
HPC is casted with and without steel fibre.The splitting tensile strength of the composite specimen with steel fibre is shown in Table 14.Fig 10 shows the variation in splitting tensile bond strength for samples with and without steel fibre.

\section{TABLE 14.Splitting Tensile Strength for specimens}

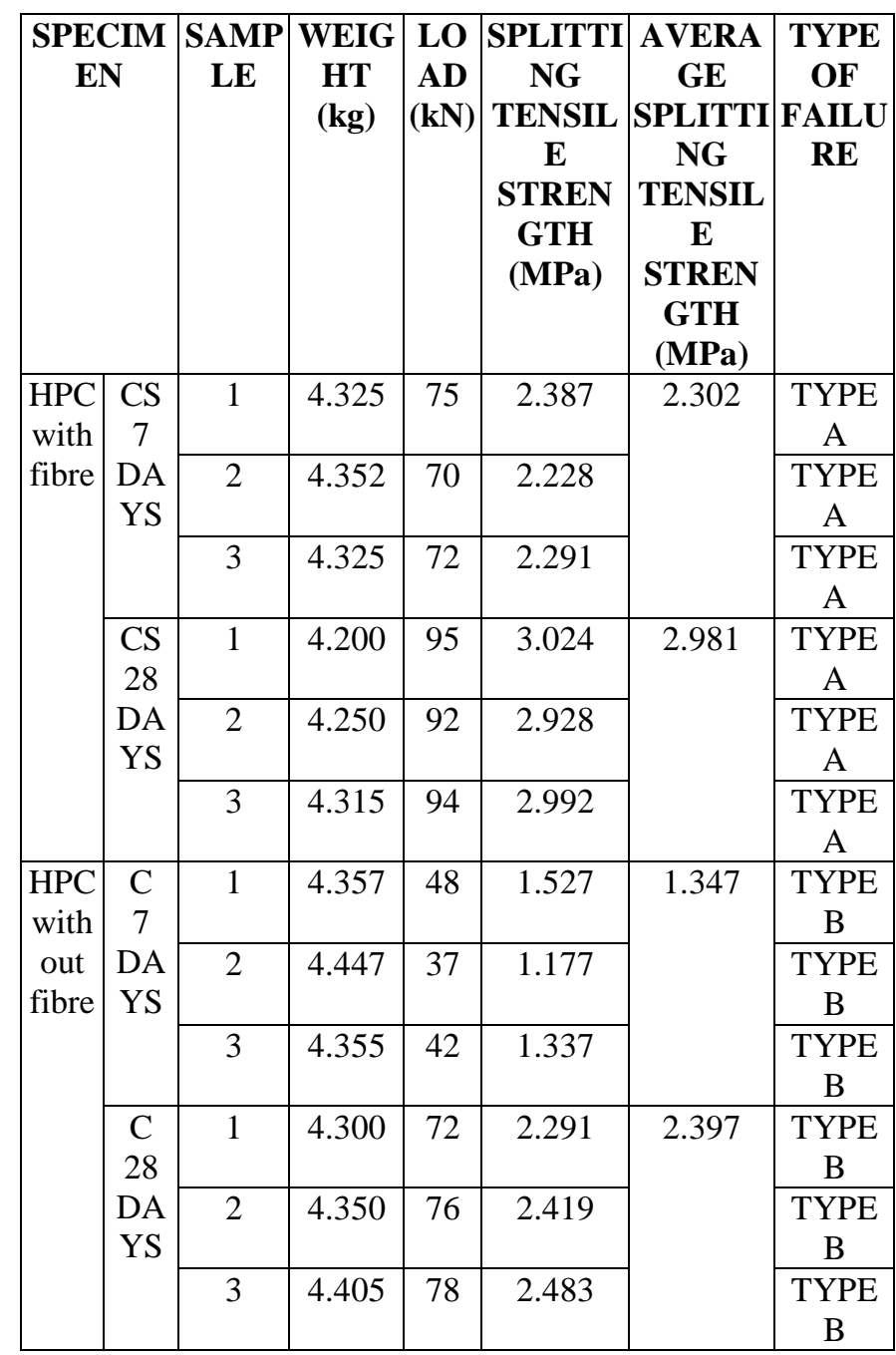

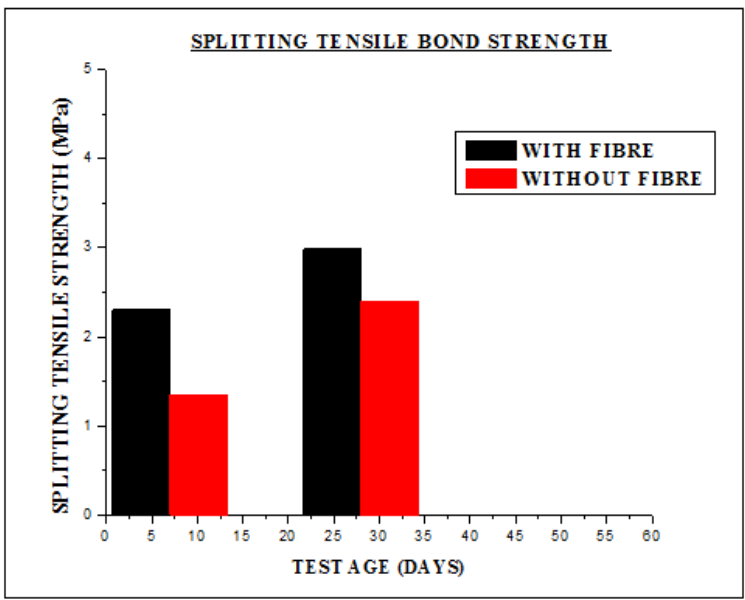

Fig 10.Splitting tensile bond strength for samples with and without steel fibre. 
TABLE 16.Quantitative bond quality in terms of bond strength

\subsection{Discussions}

\subsubsection{Slant shear bond strength}

From the slant shear test of the samples impregnated with steel fibres, the average slant shear bond strength was observed to be $12.573 \mathrm{MPa}$ and $14.195 \mathrm{MPa}$ for 7 days and 28 days testing respectively. Whereas for the samples without steel fibre, the average slant shear bond strength was observed to be $3.793 \mathrm{MPa}$ and $8.573 \mathrm{MPa}$ for 7 days and 28 days testing respectively.Therefore the average bond strength for the samples with fibre is observed to be greater than those without fibre.The interfacial bonding is found to be strong for HPC with steel fibre.

The results generally exhibit a gradual increase in interfacial bond strength with age which could be due to increase in strength of HPC as well as the interfacial bond strength of the composite. The tremendous enhancement in the shear bond strength could generally be attributed to greater adhesion and interlocking between the HPC and the roughened NC substrate surfaces.

According to ACI Concrete Repair Guide [2], materials used in concrete repair work shall have a specified minimum acceptable bond strength based on the slant shear strength as given in Table 15.This guide is useful in the selection of appropriate type of repair materials for rehabilitating deteriorated concrete structures.

\section{TABLE 15.Minimum acceptable bond strength range}

\begin{tabular}{|c|c|}
\hline DAYS & BOND STRENGTH (MPa) \\
\hline 1 & $2.76-6.9$ \\
\hline 7 & $6.9-12.41$ \\
\hline 28 & $12.41-20.68$ \\
\hline
\end{tabular}

From the study it is evident that the average bond strengths obtained were able to meet the minimum bond strength as specified in Table 15.

\subsubsection{Splitting tensile bond Strength}

From the splitting tensile test of the samples impregnated with steel fibres, the average splitting tensile bond strength was observed to be $2.302 \mathrm{MPa}$ and $2.981 \mathrm{MPa}$ for 7 days and 28 days testing respectively. Whereas for the samples without steel fibre, the average splitting tensile bond strength was observed to be $1.347 \mathrm{MPa}$ and $2.397 \mathrm{MPa}$ for 7 days and 28 days testing respectively. Therefore the average bond strength for the samples with fibre is observed to be greater than those without fibre. The interfacial bonding is found to be strong for HPC with steel fibre.

Comparing the measured tensile splitting strength of the composites with the quantitative bond strength quality proposed by Sprinkel and Ozyildirim[3] as shown in Table 16, it is very obvious that strength level achieved for 28 days test fall under an "Excellent" bonding category since the measured bond strength is higher than 2.1 MPa.

\begin{tabular}{|c|c|}
\hline BOND QUALITY & BOND STRENGTH (MPa) \\
\hline Excellent & $\geq 2.1$ \\
\hline Very good & $1.7-2.1$ \\
\hline Good & $1.4-1.7$ \\
\hline Fair & $0.7-1.4$ \\
\hline Poor & $0-0.7$ \\
\hline
\end{tabular}

\section{Conclusions}

The experiments were performed inorder to determine optimum design mix for M100 grade concrete and to study the interface behavior between normal concrete and fibre reinforced high performance concrete.

- $\quad$ The optimum design mix for M100 grade concrete was determined.The mix contains $5 \%$ replacement of Metakaolin, 10\% replacement of ALCCOFINE 1203 and $0.3 \%$ of flat crimped steel fibres.

The mechanical and durability properties of high performance concrete were studied.

- The strength of concrete was found to attain the target strength of $100 \mathrm{MPa}$.

- The concrete is less reactive to sulphate and chlorides as the reduction in compressive strengths were observed to be less than $10 \%$.Therefore, the concrete is highly resistant to sulphate attack and chloride ion penetration under severe conditions.

- $\quad$ The water absorption of sample is observed to be less than $5 \%$ and hence the concrete is less porous.

The interfacial bond characteristics between normal concrete and fibre reinforced high performance concrete were studied.

- $\quad$ The slant shear bond strength and the splitting tensile bond strength were observed to be sufficiently strong for specimens with steel fibre than those specimens without steel fibre.

- Hence fibre reinforced high performance concrete can be used to provide an effective and durable concrete repair to normal concrete.

\section{References}

[1] Bassam.A.Tayeh, B.H Abu Bakar, M.A.Megat Johari, "Mechanical and permeability properties of the interface between normal concrete substrate and ultra high performance fibre concrete overlay, " Construction and Building Materials, Vol 36, 2012, pp.538-548.

[2] Chynoweth G, Stankie RR, Allen WL, Anderson RR, Babcock WN, Barlow P, "Concrete Repair Guide.ACI Committee, " Concrete Repair Manual, Vol 546, 1996, pp.287-327.

[3] Sprinkel MM, Ozyildirim C, "Evaluation of high performance concrete overlays placed on Route 60 over Lynnhaven Inlet in Virginia, " Virginia 
Transportation Research Council, Charlottesville, 2000.

[4] ASTM-C882, "Standard test method for bond strength of epoxy-resin systems used with concrete by Slant Shear, " West Conshohocken, PA 19428; 1999.

[5] ASTM-C496, "Splitting tensile strength of cylindrical concrete, "West Conshohocken, PA 19428-2959; 1996.

[6] Nivin Philip, D Neeraja, "Mechanical properties of high performance concrete with admixtures and steel fibres, " Journal of engineering and applied sciences, Asian Research Publication Network, Vol 10, Issue 11, 2015, pp 4773-4782.

[7] IS: 10262-2009, "Guidelines for Concrete Mix Design Proportioning, " Bureau of Indian Standards, New Delhi.

[8] IS: 12269-1989, "Specification for Ordinary Portland cement 53 grade, " Bureau of Indian Standards, New Delhi.

[9] IS: 383-1970, "Specification for Coarse and Fine Aggregate from natural sources for Concrete," Bureau of Indian Standards, New Delhi.

[10] IS.2386-1963, "Methods of test for Aggregate of concrete part 1, 2, 3 and 4, " Bureau of Indian Standards, New Delhi.

[11] IS:516-1959, "Methods of test for strength of Concrete, " Bureau of Indian Standards, New Delhi.

[12] IS: 9103-1999, "Concrete admixtures-specification," Bureau of Indian Standards, New Delhi.

[13] ASTM-C642, "Standard Test Method for Density, Absorption, and Voids in Hardened Concrete, " West Conshohocken, PA 19428-2959, 2006.

[14] ACI 201.2R - 01, "Guide to Durable Concrete," ACI Committee 201 on Durability of Concrete

[15] ASTM C 452, "Standard Test Method for Potential Expansion of Portland-Cement Mortars Exposed to Sulfate, " ASTM International, West Conshohocken, PA, 2006.

[16] ASTM C 1012, "Standard Test Method for Length Change of Hydraulic-Cement Mortars Exposed to a Sulfate Solution, " ASTM International, West Conshohocken, PA, 2004.

[17] ACI 211.4R-08, "Guide for Selecting Proportions for High Strength Concrete using Portland Cement and other Cementitious Materials, ” ACI Committee 211. 